\title{
Targeting heme-oxidized soluble guanylate cyclase with BAY 58-2667 in experimental heart failure Guido Boerrigter*1, Lisa C Costello-Boerrigter ${ }^{1}$, Alessandro Cataliotti ${ }^{1}$, Harald Lapp ${ }^{2}$, Johannes-Peter Stasch ${ }^{3}$ and John C Burnett Jr ${ }^{1}$
}

\author{
Address: ${ }^{1}$ Mayo Clinic and Mayo Clinic College of Medicine, Rochester, MN, USA, ${ }^{2}$ Kardiologie, Helios-Klinikum, Erfurt, Germany and ${ }^{3}$ Pharma \\ Research Center, BayerHealthCare AG, Wuppertal, Germany \\ Email: Guido Boerrigter* - boerrigter.guido@mayo.edu \\ * Corresponding author
}

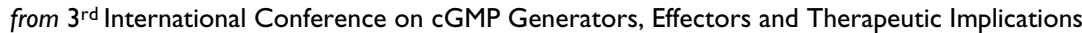

Dresden, Germany. I5-17 June 2007

Published: 25 July 2007

BMC Pharmacology 2007, 7(Suppl I):P9 doi:I0.II86/I47|-22 I0-7-SI-P9

This abstract is available from: http://www.biomedcentral.com//47I-22I0/7/SI/P9

(c) 2007 Boerrigter et al; licensee BioMed Central Ltd.

\section{Background}

Signaling via the nitric oxide (NO) - soluble guanylate cyclase (sGC) - cyclic guanosine monophosphate (cGMP) pathway is frequently impaired in cardiovascular disease states providing a rationale for enhancing it pharmacologically. Nitrovasodilators have been used for more than a century to induce vasodilation via the sGC-cGMP pathway; however, the development of tolerance and potentially adverse cGMP-independent actions of nitrovasodilators such as promoting oxidative stress and protein modification are functionally important limitations. BAY 58-2667 is a novel, NO-independent sGC activator which is not associated with the development of tolerance and which preferentially activates oxidized or heme-free sGC, which both are insensitive to endogenous $\mathrm{NO}$ and nitrovasodilators $[1,2]$. In this study we sought to define the cardiorenal actions of BAY 58-2667 as compared to nitroglycerin (NTG) in experimental heart failure (HF). We hypothesized that BAY 58-2667 would potently unload the heart and preserve renal function in a canine model of HF in a manner similar to NTG.

\section{Methods and results}

HF was induced by rapid ventricular pacing. After 10 days of pacing, cardiorenal and humoral function were assessed in an acute study at baseline and with administration of 2 doses of BAY $58-2667(0.1$ and $0.3 \mu \mathrm{g} / \mathrm{kg} /$ min; $\mathrm{n}=7$ ) or NTG ( 1 and $5 \mu \mathrm{g} / \mathrm{kg} / \mathrm{min} ; \mathrm{n}=6) .{ }^{*} \mathrm{p}<0.05$ vs. respective baseline. Administration of $0.3 \mathrm{ug} / \mathrm{kg} / \mathrm{min}$ BAY 58-2667 reduced mean arterial pressure ( $97 \pm 7$ to 68 $\left.\pm 5^{*} \mathrm{mmHg}\right)$, right atrial pressure $\left(6.7 \pm 1.1\right.$ to $3.4 \pm 0.7^{*}$ $\mathrm{mmHg})$, pulmonary artery pressure $\left(24 \pm 1\right.$ to $18 \pm 1^{*}$ $\mathrm{mmHg})$, pulmonary capillary wedge pressure $(19 \pm 1$ to $\left.12 \pm 2^{*} \mathrm{mmHg}\right)$, as well as systemic and renal vascular resistance* ${ }^{*}$. Cardiac output $\left(2.4 \pm 0.3\right.$ to $\left.3.2 \pm 0.4^{*} \mathrm{~L} / \mathrm{min}\right)$ and renal blood flow $\left(165 \pm 14\right.$ to $\left.218 \pm 16^{*} \mathrm{~mL} / \mathrm{min}\right)$ increased. Glomerular filtration rate was maintained without activation of plasma renin activity, angiotensin II, or aldosterone. In a qualitative comparison, NTG mediated similar hemodynamic and humoral changes.

\section{Conclusion}

The novel sGC activator BAY 58-2667 potently unloads the heart, increases cardiac output, and preserves glomerular filtration rate without activation of the renin-angiotensin-aldosterone system in experimental CHF. These beneficial properties make direct sGC activation with BAY 58-2667 a promising new strategy for the treatment of cardiovascular diseases such as HF. These findings also support the presence of oxidized or heme-free sGC in HF. Furthermore, as the acute hemodynamic actions of BAY 58-2667 and NTG were qualitatively similar, these findings suggest that these beneficial actions are mediated by cGMP signaling rather than cGMP-independent pathways. Potential differences in the long-term effects of BAY 
58-2667 as compared to nitrovasodilators remain to be investigated.

\section{References}

I. Stasch JP, Schmidt P, Alonso-Alija C, Apeler H, Dembowsky K, Haerter M, Heil M, Minuth T, Perzborn E, Pleiss U, Schramm M, Schroeder W, Schroder H, Stahl E, Steinke W, Wunder F: NO- and haemindependent activation of soluble guanylyl cyclase: molecular basis and cardiovascular implications of a new pharmacological principle. BrJ Pharmacol 2002, 136:773-783.

2. Stasch JP, Schmidt PM, Nedvetsky PI, Nedvetskaya TY, H S AK, Meurer S, Deile M, Taye A, Knorr A, Lapp H, Muller H, Turgay Y, Rothkegel C, Tersteegen A, Kemp-Harper B, Muller-Esterl W, Schmidt $\mathrm{HH}$ : Targeting the heme-oxidized nitric oxide receptor for selective vasodilatation of diseased blood vessels. J Clin Invest 2006, I 16:2552-256I.

Publish with Bio Med Central and every scientist can read your work free of charge

"BioMed Central will be the most significant development for disseminating the results of biomedical research in our lifetime. "

Sir Paul Nurse, Cancer Research UK

Your research papers will be:

- available free of charge to the entire biomedical community

- peer reviewed and published immediately upon acceptance

- cited in PubMed and archived on PubMed Central

- yours - you keep the copyright

Submit your manuscript here:

http://www.biomedcentral.com/info/publishing_adv.asp 